Received 27.10.2016

Reviewed 03.11.2016

Accepted 14.12.2016

A - study design

B - data collection

C - statistical analysis

D - data interpretation

$\mathbf{E}$ - manuscript preparation

F - literature search

\title{
Operating household wastewater treatment plants in the light of binding quality standards for wastewater discharged to water bodies or to soil
}

\author{
Bartosz JAWECKI ${ }^{\text {ABDEF } 凶}$, Katarzyna PAWESKA ${ }^{\text {ADF }}$, \\ Marcin SOBOTA ${ }^{\text {DF }}$
}

\begin{abstract}
Wrocław University of Environmental and Life Sciences, Faculty of Environmental Engineering and Geodesy, ul. C.K. Norwida 25, 50-375 Wrocław, Poland; e-mail: bartosz.jawecki@upwr.edu.pl, katarzyna.paweska@upwr.edu.pl, marcin.sobota@upwr.edu.pl
\end{abstract}

For citation: Jawecki B., Pawęska K., Sobota M. 2017. Operating household wastewater treatment plants in the light of binding quality standards for wastewater discharged to water bodies or to soil. Journal of Water and Land Development. No. 32 p. 31-39. DOI: 10.1515/jwld-2017-0004.

\begin{abstract}
The study presents the legal requirements concerning the quality of wastewater discharged to waterbodies and to soil after treatment in household wastewater treatment plants located in agglomerations or outside them. The procedure of stopping the operation of a household treatment plant that doesn't meet the statutory wastewater treatment efficiency was presented. The decision ordering to stop the use of a household wastewater treatment plant has to be preceded by a decision ordering to take measures to limit its adverse impact on the environment. The clarification procedure has to determine the adverse impact on the environment in a doubtless manner and it has to be reflected in the documentation. The assessment of adverse impact should take into account the binding standards of use of the environment. Stopping the operation of a household wastewater treatment plant may result in issuing a decision ordering the user to connect to the sanitary sewage system.
\end{abstract}

Key words: administrative decision, agglomeration, household wastewater treatment plant, sanitary sewage, stopping the operation of installation, wastewater treatment efficiency

\section{INTRODUCTION}

The protection of waters against the results of discharge of insufficiently treated municipal sewage results from the implementation of the Directive concerning urban wastewater treatment [Directive 91/271/EEC] to Polish law, which should lead to achieving at least a good water condition as required by the Framework Water Directive [Directive 2000/60/EC] The ordinance of the Minister of Environment, issued in 2014, laying down conditions for the introduction of sewage into water bodies or soil and laying down the list of substances particularly harmful to water environments [Rozporządzenie Mi- nistra Środowiska... 2014] has tightened the rules for discharging municipal wastewater to water or to the soil. This applies to all wastewater treatment plants, including household systems, that exist in the agglomeration area (agglomeration as defined in Art. 43, item 2 point 1 of the Water Law Act, established pursuant to Art. 43, item 2a by a resolution of the voivodeship council [Ustawa "Prawo wodne" 2001].

The Order [Rozporządzenie Ministra Środowiska... 2014], among others, imposes the obligation to increase the removal of biogenic substances on all wastewater treatment plants located in agglomerations exceeding $10000 \mathrm{PE}$, regardless of the size of the facility. As far as wastewater treatment plants located 
outside the borders of agglomerations are concerned, the requirements concerning the conditions of wastewater discharge related to total nitrogen and phosphorus were tightened [Ministerstwo Środowiska 2014]. For household wastewater treatment plants the Order [Rozporządzenie Ministra Środowiska... 2014] introduces two groups of standards: one (less restrictive) for systems located outside agglomerations and another one (more restrictive) for household wastewater treatment plants located in agglomerations. This results in a situation where certain types of household treatment plants (located in agglomerations) will have difficulties achieving the required quality standards of treated wastewater and thus their operation may be stopped by way of administrative decision.

The aim of this paper is to discuss the problems with achieving (maintaining) the statutory quality standards for wastewater discharged to waters or to soil from household wastewater treatment plants and to analyse instances when it is necessary to initiate proceedings to stop the operation of such facilities.

\section{EFFECTIVENESS OF WASTEWATER TREATMENT IN HOUSEHOLD WASTEWATER TREATMENT PLANTS}

The concentration of pollutants in domestic wastewater treated in household treatment plants is characterised by high variability. According to literature, average concentrations of pollutants vary within the range $\mathrm{BOD}_{5} 190-400$ (max. 500) $\mathrm{mg} \mathrm{O} \mathrm{O}_{2} \cdot \mathrm{dm}^{-3}$, COD 360-430 (max. 800) $\mathrm{mg} \mathrm{O}_{2} \cdot \mathrm{dm}^{-3}$, total suspended solid 210-367 (max. 583) $\mathrm{mg} \cdot \mathrm{dm}^{-3}$, total nitrogen 40-80 (max. 92) $\mathrm{mg} \mathrm{N} \cdot \mathrm{dm}^{-3}$, total phosphorus 7-15 (max. 20) $\mathrm{mg} \mathrm{P} \cdot \mathrm{dm}^{-3}$ [HEIDRICH 1998; HEIDRICH et al. 2008; HEIDRICH, STAŃKO 2007; HEIDRICH, WITKOWSKI 2005; ŁOMOTOWSKI, SZPINDOR 1999]. On the other hand, the operational efficiency of household wastewater treatment plants is defined as the percentage of the reduction of pollutants, expressed, among others, by organic matter (i.e. $\mathrm{BOD}_{5}$, $\mathrm{COD}$, total suspended solid) and biogenes (i.e. total nitrogen and phosphorus).

For smaller systems, where the flow of wastewater usually does not exceed $5.0 \mathrm{~m}^{3} \cdot \mathrm{d}^{-1}$, these requirements apply mainly to the combined physical and biological treatment methods. Organic matter reduction may be achieved by means of controlling physical processes, such as sedimentation, flotation, filtration, while microorganisms proliferating in the activated sludge or in the biofilm will be responsible for the removal of biogenic substances. The complexity of the applied methods should ensure the required degree of treatment, which is safe for the environment.

The first indispensable equipment in local wastewater treatment plants is the septic tank. It is quite often adapted from the existing holding tanks. As a flow tank of a large volume $\left(\min .3 .0 \mathrm{~m}^{3}\right.$ ) it is responsible for the proper course of physical processes that result in the reduction of suspensions even up to $80 \%$ and $\mathrm{BOD}_{5}$ to $70 \%$ [CHMIELOWSKI, BUGAJSKI 2008; CHMIELOWSKI et al. 2011; SHARMA et al. 2016]. The treatment processes that occur in septic tanks are insufficient (especially for biogenic substances) to enable the introduction of wastewater directly to the receiver such as the soil or surface waters. Thus, in order to achieve the level of reduction required by law, the septic tank should be connected to elements that ensure biological treatment.

In Poland, some of the most popular solutions for biological wastewater treatment are classic infiltration drainage systems and their modifications (such as mats or tunnels). The construction of the systems makes it impossible to control the processes that occur below the pipelines introducing wastewater to the soil, so it is difficult to claim that sewage parameters are kept on the discharge from this type of treatment plant. These systems are currently becoming undesirable or even banned in certain EU Member States, due, among others, to the problems resulting from the lack of control of their operation [BŁAŻEJEWSKI 2005; JÓŹWIAKOWSKI 2012b; JÓŹWIAKOWSKI et al. 2014; OBARSKA-PEMPKOWIAK et al. 2015b].

An alternative for drainage are systems characterised by improved control over the treatment process, including both plant-soil systems (sand filters, plantsoil deposits) and container systems with activated sludge or biofilm. Being more or less resistant to uneven inflow of wastewater, they may be applied in complex water treatment conditions in areas without central sewage systems. They are also characterised by high efficiency in the reduction of organic matter (Tab. 1).

Table 1. The range of average effectiveness (\%) of sewage treatment in various types of household wastewater treatment plant

\begin{tabular}{|c|c|c|c|c|c|c|}
\hline Type of treatment plant & $\mathrm{BOD}_{5}$ & COD & $\begin{array}{l}\text { Total } \\
\text { suspended } \\
\text { solids }\end{array}$ & $\begin{array}{l}\text { Total } \\
\text { nitrogen }\end{array}$ & $\begin{array}{c}\text { Total } \\
\text { phosphorus }\end{array}$ & Source \\
\hline 1 & 2 & 3 & 4 & 5 & 6 & 7 \\
\hline \multirow[t]{2}{*}{ Infiltration drainage } & \multicolumn{5}{|c|}{$\begin{array}{l}\text { lack of possibility to control the efficiency of operation due to lack } \\
\text { of possibility to collect samples of treated wastewater }\end{array}$} & $\begin{array}{l}\text { BŁAŻEJEWSKI 2005; JÓŹWIAKOWSKI } \\
\text { 2012a; JÓŹWIAKOWSKI et al. 2014; OBAR- } \\
\text { SKA-PEMPKOWIAK et al 2015b }\end{array}$ \\
\hline & $79.2-99.0$ & $73.0-86.0$ & $53.0-95.0$ & $19.2-35.5$ & $27.4-68.0$ & KALENIK, CHARKIEWICZ 2010*, 2013* \\
\hline Sand filter & $97.0-98.9$ & 79.3 & $84.8-93.4$ & 83.8 & 57.1 & $\begin{array}{l}\text { CHMIELOWSKI et al. 2011; CHMIELOWSKI, } \\
\text { WALĘGA } 2009\end{array}$ \\
\hline Biological deposits & $83.0-96.3$ & $83.0-93.0$ & $73.8-92.0$ & $32.1-42.0$ & $20.0-97.3$ & $\begin{array}{l}\text { MARZEC, JÓŹWIAKOWSKI 2006; JENSSEN et } \\
\text { al. 2010; JÓŹWIAKOWSKI 2012b }\end{array}$ \\
\hline
\end{tabular}




\begin{tabular}{|c|c|c|c|c|c|c|c|}
\hline & 1 & 2 & 3 & 4 & 5 & 6 & 7 \\
\hline Activated & sludge & $71.0-87.0$ & $71.0-86.0$ & $72.0-90.5$ & $40.0-67.0$ & $39.0-63.0$ & $\begin{array}{l}\text { JÓŹWIAKOWSKI 2012a; MATAMOROS et al. } \\
2016\end{array}$ \\
\hline \multirow{3}{*}{$\begin{array}{l}\text { Soil-plant } \\
\text { deposits }\end{array}$} & horizontal flow & $45.8-93.0$ & $79.9-85.9$ & $43.6-91.3$ & $49.7-69.9$ & $26.2-57.6$ & \multirow{2}{*}{$\begin{array}{l}\text { GAJEWSKA, OBARSKA-PEMPKOWIAK 2009; } \\
\text { OBARSKA-PEMPKOWIAK et al. 2015a; b }\end{array}$} \\
\hline & vertical flow & $78.5-98.1$ & $53.1-91.5$ & $29.1-93.5$ & $13.4-82.3$ & $1.9-68.2$ & \\
\hline & hybrid flow & $93.0-96.0$ & $86.0-94.0$ & $83.0-91.0$ & $19.0-66.0$ & $12.0-95.0$ & $\begin{array}{l}\text { JÓŹWIAKOWSKI et al. 2015; OBARSKA- } \\
\text { PEMPKOWIAK et al. 2015b; PAING et al. } \\
2015\end{array}$ \\
\hline \multicolumn{2}{|c|}{ Soil-plant deposits } & $95.0-98.8$ & $74.0-90.6$ & $34.0-71.0$ & $84.0-97.6$ & $98.9-99.1$ & $\begin{array}{l}\text { CZYŻYK et al. 2012; PAWĘSKA, KUC- } \\
\text { ZEWSKI } 2008\end{array}$ \\
\hline \multicolumn{2}{|c|}{ Hydroponic deposit } & 96.0 & - & 73.5 & 42.0 & 52.0 & BERGIER, WŁODYKA-BERGIER 2012 \\
\hline
\end{tabular}

* Research conducted on a test site constructed in the laboratory.

Source: own elaboration.

\section{QUALITY STANDARDS FOR WASTEWATER DISPOSED INTO WATER BODIES OR SOIL FROM HOUSEHOLD WASTEWATER TREATMENT PLANTS}

Pursuant to the Order of the Minister of Environment 2014 laying down conditions for the introduction of sewage into water bodies or soil and laying down the list of substances particularly harmful to water environments [Rozporządzenie Ministra Środowiska... 2014], wastewater disposed from household wastewater treatment plants located outside agglomerations must meet the requirements listed in Table 2 . Moreover, if wastewater is introduced into soil or water units (within the limits of land owned by the operator) its volume must not exceed $5.0 \mathrm{~m}^{3} \cdot \mathrm{d}^{-1}$ and the highest usable level of ground waters must be located at least $1.5 \mathrm{~m}$ below the bottom of the water unit or place where wastewater is introduced to soil [Rozporządzenie Ministra Środowiska... 2014].

The quality of wastewater treated in household wastewater treatment plants located in agglomera-

Table 2. Quality of wastewater disposed to the environment and originating from household wastewater treatment plants located outside agglomerations

\begin{tabular}{|c|c|c|c|c|}
\hline \multirow{2}{*}{$\begin{array}{l}\text { Indicator } \\
\text { name }\end{array}$} & \multirow{2}{*}{$\begin{array}{l}\text { Measure- } \\
\text { ment }\end{array}$} & \multicolumn{3}{|c|}{ Receiver } \\
\hline & & water bodies & water units & soil \\
\hline \multirow[t]{2}{*}{$\mathrm{BOD}_{5}$} & $\mathrm{mg} \mathrm{O}_{2} \cdot \mathrm{dm}^{-3}$ & 40 & 25 & - \\
\hline & $\begin{array}{l}\min \% \text { of } \\
\text { reduction }\end{array}$ & - & $70-90$ & 20 \\
\hline \multirow[t]{2}{*}{ COD } & $\mathrm{mg} \mathrm{O}_{2} \cdot \mathrm{dm}^{-3}$ & 150 & 125 & - \\
\hline & $\begin{array}{l}\min \% \text { of } \\
\text { reduction }\end{array}$ & - & 75 & - \\
\hline \multirow{2}{*}{$\begin{array}{l}\text { Total } \\
\text { suspended } \\
\text { solid }\end{array}$} & $\mathrm{mg} \cdot \mathrm{dm}^{-3}$ & 50 & 35 & 50 \\
\hline & $\begin{array}{l}\min \% \text { of } \\
\text { reduction }\end{array}$ & - & 90 & - \\
\hline \multirow{2}{*}{$\begin{array}{l}\text { Total } \\
\text { nitrogen }\end{array}$} & $\mathrm{mg} \mathrm{N} \cdot \mathrm{dm}^{-3}$ & $30 *$ & $15 *$ & - \\
\hline & $\begin{array}{l}\text { min \% of } \\
\text { reduction }\end{array}$ & - & - & - \\
\hline \multirow{2}{*}{$\begin{array}{l}\text { Total } \\
\text { phosphorus }\end{array}$} & $\mathrm{mg} \mathrm{P} \cdot \mathrm{dm}^{-3}$ & $5 *$ & $2 *$ & - \\
\hline & $\begin{array}{l}\min \% \text { of } \\
\text { reduction }\end{array}$ & - & - & - \\
\hline
\end{tabular}

* Values required only for wastewater disposed to lakes and their tributaries and directly to artificial water reservoirs situated on running waters.

Source: own elaboration based on $\S 4$ item $8, \S 13$ items 5 and 7 of order of the Minister of Environment [Rozporządzenie Ministra Srodowiska... 2014] tions, introduced to water bodies, water units and soil, depends on the size of the agglomeration (expressed in PE) where the treatment plants are located (Tab. 3). Moreover, if wastewater is introduced into soil or water units (within the limits of land owned by the operator) its volume must not exceed $5.0 \mathrm{~m}^{3} \cdot \mathrm{d}^{-1}$ and the highest usable level of ground waters must be located at least $1.5 \mathrm{~m}$ below the bottom of the water unit or place where wastewater is introduced to soil [Rozporządzenie Ministra Środowiska... 2014].

The Order of the Minister of Environment [Rozporządzenie Ministra Środowiska... 2014] also imposes the obligation to conduct analyses of wastewater treatment efficiency, based on the physical and chemical composition of samples collected always at

Table 3. Quality of wastewater disposed to the environment and originating from household wastewater treatment plants located in agglomerations

\begin{tabular}{|c|c|c|c|c|c|}
\hline \multirow{4}{*}{$\begin{array}{l}\text { Indicator } \\
\text { name }\end{array}$} & \multirow{4}{*}{$\begin{array}{l}\text { Measure- } \\
\text { ment unit }\end{array}$} & \multicolumn{4}{|c|}{$\begin{array}{c}\text { Receiver: } \\
\text { water bodies, water units, soil }\end{array}$} \\
\hline & & \multicolumn{4}{|c|}{$\begin{array}{l}\text { highest permissible values of pollution } \\
\text { indicators or minimum percentage of } \\
\text { reduction of pollutants for wastewater } \\
\text { introduced to water bodies or to soil in } \\
\text { agglomerations }\end{array}$} \\
\hline & & \multicolumn{4}{|c|}{ per PE agglomeration } \\
\hline & & $\begin{array}{c}2000- \\
9999\end{array}$ & $\begin{array}{l}10000- \\
14999\end{array}$ & $\begin{array}{c}15000- \\
99999\end{array}$ & $\begin{array}{l}\text { above } \\
100000\end{array}$ \\
\hline \multirow[t]{2}{*}{$\mathrm{BOD}_{5}$} & $\mathrm{mg} \mathrm{O}_{2} \cdot \mathrm{dm}^{-3}$ & 25 & 25 & 15 & 15 \\
\hline & $\begin{array}{l}\min \% \text { of } \\
\text { reduction }\end{array}$ & $70-90$ & $70-90$ & 90 & 90 \\
\hline \multirow[t]{2}{*}{ COD } & $\mathrm{mg} \mathrm{O}_{2} \cdot \mathrm{dm}^{-3}$ & 125 & 125 & 125 & 125 \\
\hline & $\begin{array}{l}\min \% \text { of } \\
\text { reduction }\end{array}$ & 75 & 75 & 75 & 75 \\
\hline \multirow{2}{*}{$\begin{array}{l}\text { Total } \\
\text { suspended } \\
\text { solid }\end{array}$} & $\mathrm{mg} \cdot \mathrm{dm}^{-3}$ & 35 & 35 & 35 & 35 \\
\hline & $\begin{array}{l}\text { min } \% \text { of } \\
\text { reduction }\end{array}$ & 90 & 90 & 90 & 90 \\
\hline \multirow{2}{*}{$\begin{array}{l}\text { Total } \\
\text { nitrogen }\end{array}$} & $\mathrm{mg} \mathrm{N} \cdot \mathrm{dm}^{-3}$ & $15^{*}$ & 15 & 15 & 10 \\
\hline & $\begin{array}{l}\text { min } \% \text { of } \\
\text { reduction }\end{array}$ & - & $\begin{array}{l}70- \\
80 * *\end{array}$ & $70-80$ & $70-80$ \\
\hline \multirow{2}{*}{$\begin{array}{l}\text { Total } \\
\text { phosphorus }\end{array}$} & $\mathrm{mg} \mathrm{P} \cdot \mathrm{dm}^{-3}$ & $2 *$ & 2 & 2 & 1 \\
\hline & $\begin{array}{l}\min \% \text { of } \\
\text { reduction }\end{array}$ & - & $80 * *$ & 80 & 80 \\
\hline
\end{tabular}

* As under the Table 2 .

** The minimum percentage of reduction does not apply to wastewater disposed to lakes and their tributaries, directly to artificial water reservoirs situated on running waters and to soil.

Source: own elaboration based on $\S 4$ item 9, $\S 13$ items 6 and 8, Appendix 3 of order of the Minister of Environment [Rozporządzenie Ministra Środowiska... 2014]. 
the same location, at regular intervals. As far as household treatment plants are concerned, samples should be collected 4 times a year. However, if the analyses demonstrate that the degree of treatment is adequate, in subsequent years samples are collected only twice a year. One should return to analysing 4 samples per year if the tests show that the degree of treatment is insufficient even once.

A wider discussion of the legal aspects of the construction and operation of household wastewater treatment plants can be found, among others, in the works of JAWECKI et al. [2016a; b], PRYSZCZ, MROWIEC [2015] BRZOSTOWSKI et al. [2008], BŁAŻEJEWSKI [2005].

\section{STOPPING THE OPERATION OF HOUSEHOLD WASTEWATER TREATMENT PLANT}

The analysis of operational effectiveness of household wastewater treatment plants (Tab. 1,2) has demonstrated that in the upper limits of wastewater treatment efficiency all the discussed treatment plants may meet the requirements for wastewater introduced to soil from facilities located outside agglomerations. On the other hand, in the lower efficiency range standards for suspensions may not be fulfilled for landplant (vertical and horizontal flow) and soil-plant wastewater treatment plants (Tab. 1, 2). If wastewater is disposed into water units or water bodies, all discussed wastewater treatment plants may have difficulties meeting the standards with respect to the lower ranges of treatment concerning the removal of suspended solid.

As far as household wastewater treatment plants located in agglomerations are concerned, all the analysed treatment plants may fail to meet the treatment standards with respect to lower values of treatment efficiency, due to low removal efficiency of suspended solid, regardless of the size of agglomeration where they are located (Tab. 1, 3). However, for the upper values of treatment efficiency, most of the wastewater treatment plants may meet the requirements imposed on facilities located in agglomerations of PE 2000-9999, with the exception of hydroponic and soil-plant treatment plants, due to insufficient degree of suspended solid removal. For agglomerations exceeding $10000 \mathrm{PE}$, most of the analysed household wastewater treatment plants may meet the requirements concerning wastewater treatment efficiency (both in the lower and upper ranges of treatment efficiency), mainly due to excessively low level of total nitrogen and total phosphorus removal (Tab. $1,3)$.

The comparison of wastewater treatment efficiency in household wastewater treatment plants (Tab. 1) with the quality standards for wastewater introduced to water bodies and to soil (Tab. 2, 3) [Rozporządzenie Ministra Środowiska... 2014] may lead to the conclusion that some household wastewater treatment plants (in particular those located in agglomerations) may fail to meet the requirements specified in the Order of The Minister of Environment [Rozporządzenie Ministra Środowiska... 2014]. Failure to meet the standards of wastewater treatment efficiency by household wastewater treatment plants may result in initiating the procedure to stop the operations of such treatment plant.

The operation of a household wastewater treatment plant (of a flow rate up to $5.0 \mathrm{~m}^{3} \cdot \mathrm{d}^{-1}$ ) does not require a permit, although it requires notifying the authorities about the operation (Art. 152, item 1, of the Polish Environmental Protection Act (hereinafter referred to as EPA [Ustawa "Prawo ochrony środowiska" 2001], § 2 item 1 of the Order on the types of installations whose operation requires a notification [Rozporządzenie Ministra Środowiska... 2010]). The competent authority to receive such notification is the Commune Head, or the Mayor of a town or city (Art. 378 , item 3, point 3 EPA) and the notification should be submitted prior to commencing the operations of a household wastewater treatment plant. The commune head or mayor of a town or city may, pursuant to Art. 154 EPA [Ustawa "Prawo ochrony środowiska" 2001] lay down the requirements of environmental protection for the operation of the installation by way of a decision. This decision applies both to installations that require notification and to such that do not require a notification or a permit [BUKOWSKI et al. 2013], i.e. also to household wastewater treatment plants. The need to issue such decision is based on reasonable protection necessity resulting from technological or environmental conditions, etc., provided that they need to be justified adequately in the grounds for the decision. Such procedure is initiated only ex officio and it may apply both to already operating and planned investments (however only with respect to installations that require notification and after submission of such notification - only then may the influence of such installation be assessed and the environmental protection requirements may be determined) [BUKOWSKI et al. 2013]. However, if a natural person fails to comply with the terms and conditions of a decision issued pursuant to Art. 154 EPA, the environmental protection authority may issue a decision to stop the operation of such installation, pursuant to Art. 368, item 1 [BUKOWSKI et al. 2013].

The commune head or mayor of a town or city may also exercise the control of compliance with, and application, of the regulations on environmental protection (Art. 379 item 1 EPA [Ustawa "Prawo ochrony środowiska" 2001]), where, as part of the inspection, it may, among others: require written or verbal information to the extent indispensable for identifying the actual state of matters (Art. 379 item 3 point 3 EPA [Ustawa "Prawo ochrony środowiska" 2001]), request access to documents and all data related to the issues covered by the inspection (Art. 379 item 3 point 4 EPA [Ustawa "Prawo ochrony środowiska" 2001]), such as the results of the quality analysis of 
wastewater disposed from household wastewater treatment plant whose operation requires notification. If it is found that the wastewater disposed from a household wastewater treatment plant fails to meet the quality standards for wastewater introduced to water bodies or to soil [Rozporządzenie Ministra Środowiska... 2014], this constitutes the basis for the determination of that such installation has an adverse impact on the environment.

As far as natural persons are concerned, the competent authorities for issuing decisions with respect to negative environmental influence of a household wastewater treatment plant are, pursuant to Art. 363 EPA, the head of the commune and the mayor of a town or city [II OSK 1380/10], provided that this applies only to natural persons who do not conduct economic activity or to cases where the use of the environment (e.g. wastewater disposal) does not require permits [IV SA/WA 2245/13]. Such competent authority, pursuant to Art. 363 EPA [Ustawa "Prawo ochrony środowiska" 2001] may, by way of a decision, order the natural person to take in a specific time measures to limit their adverse impact on the environment [II SA/G1 59/11; II OW 74/11] or, pursuant to Art. 368, item 2 EPA, by way of a decision, it may stop the use of the installation or equipment [II OW 74/11]. The public administration authority, issuing a decision pursuant to Art. 363 EPA [Ustawa "Prawo ochrony środowiska" 2001] ordering to take specific measures, should apply the criteria specified in Art. 31 , item 3 of the Constitution of the Republic of Poland [Konstytucja Rzeczypospolitej Polskiej 1997] i.e. it should impose duties only when they are necessary and only to the necessary extent. It should also analyse whether it will achieve the intended result by imposing certain duties. The criterion that should be applied by the authority when imposing duties are environmental needs [BUKOWSKI et al. 2013]. It should be noted that proceedings conducted pursuant to Art. 363 and 368 EPA [Ustawa "Prawo ochrony środowiska" 2001] may only be initiated ex officio (Art. 375 EPA [Ustawa "Prawo ochrony środowiska" 2001]) [IV SA/Wa 2245/13].

The basis for the application of Art. 363 EPA [Ustawa "Prawo ochrony środowiska" 2001] Is the determination of the state defined as "adverse impact on the environment" of the household wastewater treatment plant. This term refers to situations when the binding standards of the use of environment are violated [II SA/Gl 59/11; GRUSZECKI 2008]. According to GRUSZECKI [2008], "This means that if, as a result of actions of natural persons who do not conduct economic activity, soil or waters have been contaminated, then the executive authority of the commune shall be obliged to issue a decision ordering them to take in a specific time measures to limit their adverse impact on the environment. However, if the administrative authority is unable to specify the essence and the scale of the said adverse impact, then it should consider whether, in the given situation, it is not dealing with disturbances (not adverse impact on the environment), which do not have to be identified with adverse impact, as they may be caused by actions that do not lead to non-compliance with binding standards of the use of environment, but only, for example, limiting the possibility to use adjacent property" [II SA/Gl 59/11].

The evaluation concerning "adverse impact on the environment" should take into account binding standards of the use of environment (including The Regulation of the Minister of Environment laying down conditions for the introduction of sewage into water bodies or soil and laying down the list of substances particularly harmful to water environments [Rozporządzenie Ministra Środowiska... 2014]), whose violation (infringement) even if legal, may cause adverse effects, and thus opens the possibility to issue, pursuant to Art. 363 EPA [Ustawa "Prawo ochrony środowiska" 2001] a decision, ordering the natural person whose activity has an adverse impact on the environment, to take in a specific time measures to limit such impact [II SA/Gl 59/11]. However, the application of Art. 363 EPA [Ustawa "Prawo ochrony środowiska" 2001] requires clear evidence (as determined on the explanatory stage of administrative proceedings) confirming that the adverse impact on the environment actually exists [IV SA/Wa 750/10], which should be duly justified in the decision based on the collected evidence material [SA/Sz 1957/03].

If the natural person who is e.g. operating a household wastewater treatment plant, fails to comply with the decision ordering them to take in a specific time measures to limit their adverse impact on the environment, the head of the commune or mayor of a town or city may (pursuant to Art. 368, item 2 EPA [Ustawa "Prawo ochrony środowiska" 2001]) by way of a decision, stop the use of the installation or equipment.

It should be emphasised that the authority conducting the proceedings should always first of all consider, what type of measures might lead to the elimination of the adverse impact. If it determines that it is possible to take action limiting the adverse impact, such authority should conduct proceedings pursuant to Art. 363 EPA [Ustawa "Prawo ochrony środowiska" 2001] because omitting it and adjudicating pursuant to Art. 368 [Ustawa "Prawo ochrony środowiska" 2001] might result in charging the administrative authority with non-compliance of the applied legal measures with the existing factual state. If, in the opinion of the authority, it is impossible to issue a decision pursuant to Art. 363 EPA [Ustawa "Prawo ochrony środowiska" 2001], this should be reflected in the grounds. What is important is the fact that such assessment has to be correctly conducted in all cases when the authority issues a decision to stop the operation pursuant to Art. 368, item 1, without prior adjudication pursuant to Art. 363 EPA [BUKOWSKI et al. 2013; GRUSZECKI 2008; Ustawa "Prawo ochrony środowiska" 2001]. 


\section{SUMMARY}

The implementation of more rigorous standards to be met by wastewater introduced to water bodies or to soil since the 1.01.2016 yr. and introducing two sets of standards for household wastewater treatment plants $\left(1^{\text {st }}\right.$ set for treatment plants located in agglomerations and the $2^{\text {nd }}$ one for those outside agglomerations) has led to a situation when part of household water treatment solutions (especially in plants located in agglomerations) may fail to achieve the wastewater treatment degree required by law. The review of data contained in subject literature demonstrates that the problem with achieving the treatment efficiency required by law may apply to all analysed household wastewater treatment plants located in agglomerations of PE exceeding 10000 , mainly due to insufficient level of total nitrogen and phosphorus removal.

The competent authorities for the control of household wastewater treatment plants operated by natural persons (who do not conduct economic activity and do not have a water permit) are the head of the commune or mayor of the town or city (Art. 5, item 6 of the Act on maintaining cleanliness and order in municipalities (hereinafter: AMCOM) [Ustawa o utrzymaniu czystości i porządku w gminach 1996] Art. 379 EPA [Ustawa "Prawo ochrony środowiska" 2001]).

The head of the commune or mayor of a town, or president of the city, after finding negative impact on the environment and ineffective decision ordering to remove their adverse impact on the environment, issue an administrative decision to stop the use of the household wastewater treatment plant. The result of decision to stop the operation of a household wastewater treatment plant is the inability to use it.

Stopping the operation of a household wastewater treatment plant results in the fact that the owner of the real property equipped with the plant no longer meets the requirements specified in Art. 5, item 2 AMCOM [Ustawa o utrzymaniu czystości i porządku w gminach 1996]. It seems correct to state that in such situation, the owner is obliged to equip the real property with a collection tank or connection to collective sewage system (Art. 5, item 2 AMCOM [Ustawa o utrzymaniu czystości i porządku w gminach 1996])

If the real property equipped with a household wastewater treatment plant whose operation was stopped is located in an area with a collective sewage system, it seems possible to issue a decision pursuant to Art. 5, item 7 AMCOM [Ustawa o utrzymaniu czystości i porządku w gminach 1996] ordering to connect to the existing sanitary sewage system. It should be noted that the nature of the decision ordering to connect to the sewage system is not discretionary (IV SA/Po 4/13, II SA/G1 597/14) and that it has to be issued provided that the prerequisites specified in Art. 5, item 2 AMCOM [Ustawa o utrzymaniu czystości I porządku w gminach 1996] exist. It may seem disputable whether one may actually issue an order to connect to the sewage system if there is an existing household wastewater treatment plant. However, it seems that if such treatment plant fails to meet the degree of treatment required by law and if, due to failure to limit its adverse impact on the environment a binding decision is issued to stop the use thereof, then the circumstances releasing owners of such household wastewater treatment plants from the obligation to connect to the sewage system cease to exist, as such treatment plant does not meet the requirements specified in separate regulations. However, the presented point of view requires further analyses, considerations and discussion, the results of which will be presented in further publications.

\section{CONCLUSIONS}

1. Household wastewater treatment plants located in agglomerations of an PE above 10000 may fail to meet the requirements specified in the regulations on introducing wastewater to water bodies or to soil due to insufficient wastewater treatment efficiency (mainly removal of total phosphorus and nitrogen), and thus their operation in agglomerations seems doubtful.

2. The decision ordering to stop the use of a household wastewater treatment plant has to be preceded by a decision ordering to take in a specific time measures to limit its adverse impact on the environment.

3. The clarification procedure has to determine the adverse impact on the environment in a doubtless manner and it has to be reflected in the documentation. The assessment of such adverse impact should take into account the binding standards of use of the environment.

4. The wording of the Environmental Protection Act, stating that the head of the commune or mayor of a town or city "may" by way of decision, order a natural person to take in a specific time measures to limit their adverse impact on the environment and „may" stop the use of the installation or equipment results in the fact that such decisions become arbitrary, based on individual assessment of the authority, who may decide that issuing such decision would be unreasonable, regardless of the insufficient wastewater treatment degree.

\section{REFERENCES}

Bergier T., WŁodyKa-Bergier A. 2012. Efektywność oczyszczania ścieków w przydomowej oczyszczalni hydrofitowo-biologicznej [The efficiency of wastewater treatment in household wetland and biological treatment plant]. Woda-Środowisko-Obszary Wiejskie. T. 12. Z. 1 (37) p. 25-36.

BŁAŻEJEWSKI R. 2005. Aktualny status prawny przydomowych oczyszczalni ścieków i perspektywy ich rozwoju [Current legal status of household wastewater treatment plants and development perspectives]. WodociagiKanalizacja. Nr 10 p. 24-25.

BŁAŻEJEWSKI R. 2006. Wybrane problemy projektowania przydomowych oczyszczalni ścieków [Selected prob- 
lems of the design of household wastewater treatment plants] [online]. [Access 10.09.2015]. Available at: http:www.haba.pl/images/Bucharzewo/Bucharzewo 2006b.pdf

Brzostowski N., HaWryŁyszyn M., Karbowski D., PANICZKO S. 2008. Przydomowe oczyszczalnie ścieków poradnik [Household wastewater treatment plants a guide]. Białystok. Polska Stacja Przyrodnicza Narew. pp. 88.

Bukowski Z., Czech E., Karpus K., Rakoczy B. 2013. Prawo ochrony środowiska. Komentarz [Environmental Protection Law - Act. A commentary]. Warszawa. LexisNexis. ISBN 978-83-278-0220-0 pp. 824.

CHMielowsKi K. BUGAJSKI P. 2008. Efektywność usuwania zanieczyszczeń w osadnikach gnilnych typu „Duofilter” [Efficiency of the removal of pollutants in "Duofilter" septic tanks]. Infrastruktura i Ekologia Terenów Wiejskich. $\mathrm{Nr} 5$ p. 41-49.

Chmielowski K., Watęga A. 2009. Filtry piaskowe o przepływie pionowym jako drugi stopień oczyszczania małych ilości ścieków bytowych [Vertical flow sand filters as the second degree of treatment of low amounts of domestic sewage]. Infrastruktura i Ekologia Terenów Wiejskich. Nr 6 p. 109-119.

Chmielowski K., SLizowski R. Pęgiel K. 2011. Ocena działania przydomowej oczyszczalni ścieków z filtrem piaskowym o przepływie poziomym [Evaluation of the operation of a household wastewater treatment plant with a horizontal flow sand filter]. Infrastruktura i Ekologia Terenów Wiejskich. Nr 2 p. 215-223.

Czyżyk F., Pulikowski K., Strzelczyk M., Pawęska K. 2012. Efektywność oczyszczania ścieków bytowo-gospodarczych w oczyszczalniach gruntowo-roślinnych i glebowo-roślinnych [Efficiency of wastewater treatment in land-plant and soil-plant treatment systems]. Woda-Środowisko-Obszary Wiejskie. T. 12. Z. 4 (40) p. $97-108$.

Council Directive 91/271/EEC concerning urban wastewater treatment. OJ 135 of 30.5.1991, incl. amendments.

Directive of the European Parliament and of the Council 2000/60/EC establishing a framework for the Community action in the field of water policy. OJ L 327, 22.12.2000, p.1 incl. amendments.

Gajewska M., Obarska-PempKOWiaK H. 2009. 20 lat doświadczeń z eksploatacji oczyszczalni hydrofitowych w Polsce [20 years of experience of hybrid constructed wetlands exploitation in Poland]. Rocznik Ochrona Środowiska. Nr 11. p. 875-888.

GrusZeCKI K. 2008. Prawo ochrony środowiska. Komentarz. [Act - Environmental Protection Law. A commentary]. Warszawa. LEX Wolters Kluwer Polska. ISBN 978-83-7601-120-2 pp. 1131.

HeIDRICH Z. 1998. Przydomowe oczyszczalnie ścieków poradnik. [Household wastewater treatment plants A guide]. Warszawa. Centralny Ośrodek Informacji Budownictwa. ISBN 83-85393-55-2 pp. 220.

Heidrich Z., Kalenik M., Podedworna J, Stańko G. 2008. Sanitacja wsi [Rural sanitation]. Warszawa. Siędel-Przywecki. ISBN 978-83-60956-04-5 pp. 374.

HeIDRICH Z., StAŃKO G. 2007. Leksykon przydomowych oczyszczalni ścieków [Lexicon of domestic wastewater treatment plant]. Warszawa. Seidel-Przywecki. ISBN 978-83-919449-9-8 pp. 128.

HEIDRICH Z., WITKOWSKI 2005. Urządzenia do oczyszczania ścieków [Wastewater treatment equipment]. Warszawa. Seidel-Przywecki. ISBN 83-919449-4-8 pp. 287.
II OSK 1380/10 - Wyrok Naczelnego Sądu Administracyjnego $\mathrm{z}$ dnia 27.09.2011r. [Judgment of the Supreme Administrative Court of the 27.09.2011] [online]. [Access 11.01.20161]. Available at: http://orzeczenia.nsa. gov.pl/doc/A8959D4854

II OW 74/11 - Postanowienie Naczelnego Sądu Administracyjnego $\mathrm{z}$ dnia $15.09 .2011 \mathrm{r}$. [Decision of the Supreme Administrative Court of the 15.09.2011] [online]. [Access 11.01.2016]. Available at: http://orzeczenia. nsa.gov.pl/doc/525DF3E04C

II SA/Gl 59/11 - Wyrok Wojewódzkiego Sądu Administracyjnego w Gliwicach z dnia 19.05.2011 r. [Judgment of the Voivodeship Administrative Court in Gliwice of the 19.05.2011] [online]. [Access 11.01.2016]. Available at: http://orzeczenia.nsa.gov.pl/doc/CE2AFAEA09

II SA/Gl 597/14 - Wyrok Wojewódzkiego Sądu Administracyjnego w Gliwicach z dnia 15.10.2014 r. [Judgment of the Voivodeship Administrative Court in Gliwice of the 15.10.2014] [online]. [Access 19.01.2016]. Available at: http://orzeczenia.nsa.gov.pl/doc/ $91544 \mathrm{C} 7772$

IV SA/Po 4/13 - Wyrok Wojewódzkiego Sądu Administracyjnego w Poznaniu z dnia 27.03.2013 r. [Judgment of the Voivodeship Administrative Court in Poznan of the 27.03.2013] [online]. [Access 19.01.2016]. Available at: http://orzeczenia.nsa.gov.pl/doc/C4FE1D89F5

IV SA/Wa 750/10 - Wyrok Wojewódzkiego Sądu Administracyjnego $\mathrm{w}$ Warszawie $\mathrm{z}$ dnia 25.08.2010 r. [Judgment of the Voivodeship Administrative Court in Warsaw of the 25.08.2010] [online]. [Access 11.01.2016]. Available at: http://orzeczenia.nsa.gov.pl/doc/ D7EEB78D6C

IV SA/Wa 2245/13 - Wyrok Wojewódzkiego Sądu Administracyjnego w Warszawie z dnia 13.02.2014 r. [Judgment of the Voivodeship Administrative Court in Warsaw of the 13.02.2014] [online]. [Access 11.01.2016]. Available at: http://orzeczenia.nsa.gov.pl/doc/ 3C03381920

Jawecki B., Marszalek J., Pawęska K., Sobota M., MalCZEWSKA B. 2016a. Budowa i funkcjonowanie przydomowych oczyszczalni ścieków w świetle obowiązujących przepisów. Cz. 1 [The construction and operation of household wastewater treatment plants in the light of binding legislation, part 1]. Infrastruktura i Ekologia Terenów Wiejskich, Nr II/2 p. 501-516.

Jawecki B., MarszaleK J., PAwęSKa K., Sobota M., MalCZEWSKA B. 2016b. Budowa i funkcjonowanie przydomowych oczyszczalni ścieków w świetle obowiązujących przepisów. Cz. 2 [The construction and operation of household wastewater treatment plants in the light of binding legislation, part 2] Infrastruktura i Ekologia Terenów Wiejskich. Nr II/2 p. 569-580.

Jenssen P.D., Krogstad T., Paruch A., Mehlum T., Adam K., ARias C.A., Heistad A., Jonsson L., HellStröm D., BriX H., Yli-Halla M. VRÅle L., Valve M. 2010. Filter bed system treating domestic wastewater in the Nordic countries - performance and reuse of filter media. Ecological Engineering. No 36 (12) p. 16511659.

JÓŹWIAKOWSKi K. 2012a. Przydomowe oczyszczalnie ścieków na terenach wiejskich - Cz. II [Household wastewater treatment plants in rural areas - part II]. Inżynier Budownictwa. Nr 11 (100) p. 78-81.

JóźWIAKOWSKI K. 2012b. Przydomowe oczyszczalnie ścieków na terenach wiejskich - Cz. III [Household wastewater treatment plants in rural areas - part III]. Inżynier Budownictwa. Nr 12 (101) p. 60-64. 
Jóźwiakowski K., Mucha Z., Generowicz A., Baran S., BIELIŃSKA J. 2015. The use of multi-criteria analysis for selection of technology for a household WWTP compatible with sustainable development. Archives of Environmental Protection. No. 41 (3) p. 76-82.

Jóźwiakowski K., Steszzuk A., Pieńko A., Marzec M., PYTKA A., Gizińska M., Sosnowska B., OzOnek J. 2014. Ocena wpływu przydomowych oczyszczalni ścieków z drenażem rozsączającym na jakość wód podziemnych w studniach kopanych i głębinowych [The evaluation of the influence of household wastewater treatment plants on ground water quality in hand dug or deep drilled wells]. Inżynieria Ekologiczna. $\mathrm{Nr} 39$ p. 74-84.

KaleniK M., Charkiewicz J. 2010. Porównanie skuteczności oczyszczania ścieków w złożach gruntowych pod drenażem rozsączającym ścieki [Comparison of wastewater treatment efficiency in soil deposits under infiltration drainage systems]. Infrastruktura i Ekologia Terenów Wiejskich. Nr 1 p. 75-88.

KALENIK M., ChARKIEWICZ J. 2013. Skuteczność oczyszczania ścieków w żwirze pod drenażem rozsączającym ścieki [The efficiency of wastewater treatment in gravel under infiltration drainage systems]. Rynek Instalacyjny. Nr 10 p. $80-83$.

Konstytucja Rzeczypospolitej Polskiej z dnia 2 kwietnia $1997 \mathrm{r}$. [Constitution of the Republic of Poland of April 2, 1997]. Dz.U. 1997. Nr 78 poz. 483 incl. amendments.

Łomotowski J., SzPINDOR A. 1999. Nowoczesne systemy oczyszczania ścieków [Modern wastewater treatment systems]. Warszawa. Arkady. ISBN 83-213-4139-X pp. 456.

MARZEC M., JÓŹWIAKOWSKI K. 2006. Wstępna analiza funkcjonowania małej oczyszczalni ścieków ze złożem biologicznym [Preliminary analysis of the operation of a small wastewater treatment plant with a biological deposit]. Zeszyty Naukowe Akademii Rolniczej w Krakowie. Ser. Inżynieria Środowiska. Nr 28 p. 123-130.

Matamoros V., Rodriguez Y., Albaiges J. 2016. A comparative assessment of intensive and extensive wastewater treatment technologies for removing emerging contaminants in small communities. Water Research. Vol. 88 p. $777-785$.

Ministerstwo Środowiska 2014. Uzasadnienie do rozporządzenia Ministerstwa Środowiska w sprawie warunków, jakie należy spełnić przy wprowadzaniu ścieków do wód lub do ziemi oraz w sprawie substancji szczególnie szkodliwych dla środowiska wodnego [Grounds for the Regulation of the Minister of the Environment laying down conditions for the introduction of sewage into water bodies or soil and laying down the list of substances particularly harmful to water environments] [online]. [Access 15.12.2015]. Available at: http://legislacja.rcl.gov.pl/projekt/210515/katalog/210522 \#210522.

OBARSKA-PEMPKOWIAK H., GAJEWSKA M., WOJCIECHOWSKA E. 2015a. Efficiency of wastewater treatment in single-family constructed wetlands in Kaszuby Lake District. Rocznik Ochrona Środowiska. Nr 15 p. 81-95.
Obarska-Pempkowiak H., Kolecka K., Gajewska M., WOJCIECHOWSKA E., OSTOJSKI A. 2015b. Zrównoważone gospodarowanie ściekami na przykładzie obszarów wiejskich [Sustainable wastewater management based on the example of rural areas]. Rocznik Ochrona Środowiska. Nr 17 p. 585-602.

Paing J. Guilbert A., Gagnon V., Chazarenc F. 2015. Effect of climate, wastewater composition, loading rates, system age and design on performances of French vertical flow constructed wetlands: A survey based on 169 full scales systems. Ecological Engineering. No. 80 p. $46-52$.

PAWĘSKa K., KUCZEWSKI K. 2008. Skuteczność oczyszczania ścieków bytowych w oczyszczalniach roślinnoglebowych o różnej eksploatacji [Efficiency of domestic sewage treatment in soil-plant treatment plants of various types of operation]. Monografie. Nr 60. Wrocław. Uniwersytet Przyrodniczy. ISBN 978-83-60574-34-8 pp. 156.

PryszCZ M., MrowieC B.M. 2015. Funkcjonowanie przydomowych oczyszczalni ścieków w Polsce [Functioning of household wastewater treatment plants in Poland]. Inżynieria Ekologiczna. $\mathrm{Nr} 41$ p. 133-141.

Rozporządzenie Ministra Środowiska z dnia 18 listopada 2014 r. w sprawie warunków, jakie należy spełnić przy wprowadzaniu ścieków do wód lub do ziemi, oraz w sprawie substancji szczególnie szkodliwych dla środowiska wodnego [Order of the Minister of Environment of November 18, 2014 laying down conditions for the introduction of sewage into water bodies or soil and laying down the list of substances particularly harmful to water environments]. Dz.U. 2014 poz. 1800.

Rozporządzenie Ministra Środowiska z dnia 2 lipca 2010 r. w sprawie rodzajów instalacji, których eksploatacja wymaga zgłoszenia. [Order of the Minister of the Environment of July 2, 2010 on types of installations whose operation requires notification]. Dz.U. 2010. Nr 130 poz. 880.

SA/Sz 1957/03 - Wyrok Wojewódzkiego Sądu Administracyjnego w Szczecinie z dnia 17.03.2005 r. [Judgment of the Voivodeship Administrative Court in Szczecin of the 17.03.2005] [online]. [Access 19.01.2016]. Available at: http://orzeczenia.nsa.gov.pl/doc/6F4FD49BD9

Sharma K.M., Tyagib V. K., SAinia G., Kazmia A.A. 2016. On-site treatment of source separated domestic wastewater employing anaerobic package system. Journal of Environmental Chemical Engineering. No 4 p. 1209-1216.

Ustawa z dnia 13 września 1996 r. o utrzymaniu czystości i porządku w gminach [Act of September 13, 1996 on maintaining cleanliness and order in municipalities]. Dz.U. 2013 poz. 1399 incl. amendments.

Ustawa $\mathrm{z}$ dnia 18 lipca $2001 \mathrm{r}$. Prawo wodne [Act of July 18, 2001 - Water Law]. Dz.U. 2015 poz. 469 incl. amendments.

Ustawa z dnia 27 kwietnia 2001 r. Prawo ochrony środowiska [Act of April 27, 2001 Environmental Protection Law]. Dz.U. 2013 poz. 1232 incl. amendments. 


\section{Bartosz JAWECKI, Katarzyna PAWĘSKA, Marcin SOBOTA}

Użytkowanie przydomowych oczyszczalni ścieków w świetle obowiązujących standardów jakości ścieków odprowadzanych do wód lub do ziemi

\section{STRESZCZENIE}

W pracy przedstawiono wymogi prawne, dotyczące jakości ścieków wprowadzanych do wód i do ziemi po oczyszczeniu w przydomowych oczyszczalniach ścieków zlokalizowanych na terenie aglomeracji lub poza nią. Wskazano procedurę wstrzymania eksploatacji przydomowej oczyszczalni ścieków, w sytuacji gdy nie spełnia ona wymaganej przepisami skuteczności oczyszczania ścieków. Decyzja o wstrzymaniu eksploatacji przydomowej oczyszczalni ścieków musi być poprzedzona decyzją nakazującą ograniczenie negatywnego oddziaływania przydomowej oczyszczalni ścieków na środowisko. Postępowanie wyjaśniające negatywne oddziaływanie na środowisko musi zostać stwierdzone w sposób niebudzący wątpliwości oraz znajdować odzwierciedlenie w dokumentacji postępowania, a ocena negatywnego oddziaływania na środowisko powinna uwzględniać obowiązujące standardy korzystania ze środowiska. Konsekwencją wstrzymania eksploatowanej przydomowej oczyszczalni może być wydanie decyzji nakazującej podłączenie się do kanalizacji sanitarnej.

Słowa kluczowe: aglomeracja, decyzja administracyjna, kanalizacja sanitarna, przydomowa oczyszczalnia ścieków, skuteczność oczyszczania ścieków, wstrzymanie eksploatacji instalacji 